\title{
A Multidimensional Approach to Assessing the Leverage Factors of the Sustainability of Seaweed Farming in Coastal Area of Parigi Moutong District, Indonesia
}

\author{
Alimudin Laapo $^{1 *}$, Dafina Howara ${ }^{1}$, Saharia Kassa ${ }^{1}$, Hardianti Sultan ${ }^{1}$ and Abd. \\ Rahim $^{2}$ \\ ${ }^{1}$ Department of Agricultural Socio-economics, Faculty of Agriculture, Tadulako University, Jl. \\ Soekarno-Hatta Km. 9 Tondo Kota Palu 94117, Indonesia \\ ${ }^{2}$ Department of Economics, Faculty of Economics, Universitas Negeri Makassar, Jl. A.P. Pettarani \\ Gunungsari Makassar 90222, Indonesia
}

*Correspondence :

alimudinlaapo@untad.ac.id

Received : 2021-01-05

Accepted : 2021-03-22

Keywords :

Sustainability Status, Important attribute, Rapfish Technic, Seaweed Cultivation

\begin{abstract}
The sustainability of seaweed cultivation is influenced by multidimensional factors such as the quality of the aquatic environment, cultivation technology, economic contribution to cultivators, social conditions of the community, and government institutional support. This paper aims to reveal the leveraging factors for the sustainability of seaweed cultivation in the coastal area of Parigi Moutong Regency by using a multidimensional scaling approach and the RAPFISH application. The results showed that the sustainability of seaweed cultivation in the coastal area of Parigi Moutong Regency was in the less sustainable category. Leveraging factors that play an important role in the sustainability of seaweed farming are employment at the cultivator level and the feasibility of cultivation as a good factor, while the low quality of seeds of seaweed, socio-cultural capital, and fluctuating commodities prices are categorized as bad factors.
\end{abstract}

\section{INTRODUCTION}

Seaweed cultivation is a mariculture system in coastal areas that has several sub-systems or dimensions which are interrelated and integrated. These interrelated and integrated dimensions include the socio-ecological dimension (Martinez et al., 2017), and the economic dimension (Eranza et al., 2017; de Alencar et al., 2020). Vulnerability in the ecological dimension is generally related to the decline in the quality of coastal waters as a cultivation area caused by anthropogenic activities on land and coast as well as extreme global climate change (Erlania and Radiarta, 2014; Chen, 2019) and the implementation of policies that are always bias than planned (Irfan et al., 2020). Anthropogenic activities such as disposal of agricultural waste and plastic pollution (Rech et al., 2018; Jalil et al., 2020), runoff from logging waste and through river flow, mining activities (sand and nickel), and disposal waste from land to coastal areas is thought to be the main source of pollution that causes growth disruption and cessation of seaweed cultivation (Husrin et al., 2016; Ellis et al., 2017), including in the province of Central Sulawesi, Indonesia.

On the other hand, the condition of the coastal waters of Parigi Moutong Regency, Central Sulawesi Province, 
which is located in Tomini Bay, apart from having the characteristics of fertile waters, many island clusters, sandy seabed waters, and many stretches of coral reefs, but this area also has sea characteristics of rather deep waters. Although the water conditions are potential for the development of seaweed cultivation, the area of water area suitable for seaweed cultivation is also limited. The potential of coastal waters in Parigi Moutong Regency is estimated to be more than $106,989.53$ hectares or the potential production is 93,194.14 dry tons/planting season.

Coastal waters that have been used for the cultivation of seaweed with the type of Kappaphycus alvarezii or often called Eucheuma cottonii are an area of 7,429.49 hectares with dry seaweed production in 2018 of $7,798.00$ tons (BPS, 2020). Another obstacle to the development of seaweed cultivation in the ecological dimension is the limited availability of superior seeds for cultivators. The use of seeds by cultivators only relies on their cultivation products obtained from the previous harvest. On the other hand, to be able to develop properly, seaweed cultivation requires seeds that have high growth rates and are disease resistant (Yong et al., 2014a). Besides, problems were also found in the social and technological dimensions, namely the low knowledge of cultivators about identifying the suitability of marine waters for seaweed cultivation areas (Chen, 2019), selecting superior seeds, preventing and overcoming "ice-ice" disease, and still limited mastery of cultivation technology (Effendy et al., 2016).

Especially in the economic dimension, problems that often occur at the cultivator level are fluctuations and low selling prices of dried seaweed (Valderrama et al., 2013), which are thought to be caused by the limited knowledge of farmers regarding price information at the industrial and consumer levels so that the farmers' bargaining position is weak (Arsyad et al., 2014). The absence of the processing industry, weak trading, and marketing system, and an irregular logistics and distribution system (van den Burg et al., 2021) have resulted in the commodity prices of seaweed fluctuating, especially with the large number of speculators who appeared during the main harvest. Indonesian government institutional support through the Rural Fisheries Business Program (PUMP) based on aquaculture has not had maximum success. This is thought to be due to the factor of low knowledge in seaweed cultivation techniques, and the ineffective role of cultivator groups' institutions (Topcon, 2014).

The lack of integration between dimensions in the seaweed cultivation business shows that the management of seaweed agribusiness by business actors ranging from producers of input and cultivation technology, cultivators, distributors and marketers, processing industries, and the government as a facilitator has not been integrated so that the business is not sustainable. The tendency of damage to the coastal environment is more due to the development paradigm and practices that have not been by the principles of sustainable development, tends to be of an extractive nature and is dominated by the economic interests of a certain elite group and ignores the economic interests of local communities (Laapo and Howara, 2016). For the management of seaweed cultivation to be more integrated among business actors, and to support each other between dimensions, this study aims to reveal the important factors that influence the sustainability of seaweed cultivation on the coast of Parigi Moutong Regency, Central Sulawesi Province, Indonesia with multidimensional scaling (MDS) approach. The MDS approach has been widely used to assess the status of sustainable fisheries resource management based on ecological, economic, ethical, social and technological dimensions (Pitcher and Preikshot, 2001; Pitcher et al., 2013; Lam, 2016) using the Rapid Appraisal For Fisheries (RAPFISH) 
technique (Kavanagh and Pitcher, 2004). Several studies on the sustainability of seaweed cultivation have been carried out partially and jointly on the fivedimensional attribute (Marzuki et al., 2014; Soejarwo, Yusuf and Zulham, 2019; Irfan et al., 2020). However, the result of combining the attributes of the five dimensions results in an inaccurate analysis of important factors in the sustainability of seaweed management. This is because the use of attributes in the RAPFISH tool for each ordination result should not be more than 20 (twenty) attributes. For this reason, in this study, the merging of the five dimensions of development sustainability (ecology, economy, social, technology and institutions) is carried out by selecting two to three attributes that provide the largest (dominant) leverage (Root Mean Square, RMS) affecting the sustainability of each management dimension produced by previous research.

\section{METHODOLOGY}

\section{Place and Time}

The research target areas include Kasimbar District and Mepanga District as seaweed-producing centers in Parigi Moutong Regency. This research was conducted between August - November 2020.

\section{Research Materials}

The research object was four groups of seaweed cultivation that participated in the PUMP program for aquaculture (each group consists of 20 members), local collectors, exporters, and processors, as well as government officials. The consideration of selecting the study sample is membership in the cultivator group and the knowledge of cultivator members in cultivation business activities and group activities. Based on the results of discussions with the Department of Marine Affairs and Fisheries of Central Sulawesi Province, four groups of cultivators were selected, in which two groups were categorized as sufficient to succeed and two groups were categorized as not / less successful in managing their cultivation businesses. The interviewed respondents were the group leader, treasurer, and one member of the cultivator group. Meanwhile, the types and numbers of marketers and processors are adjusted to the number of actors in the two sub-districts.

\section{Research Design}

The type of data collected to answer the research objectives is based on dimensions that are proxied into several factors that affect the sustainability of seaweed cultivation, such as the suitability of marine areas for seaweed cultivation, the availability and price of production inputs for cultivators, the cultivation technology used, market availability, information on commodity prices, cultivator income, industry players, marketing actors, the role of cultivator groups, and the role of institutions by the government in program implementation. This type of data is obtained from the results of interviews with cultivators, processing industries, and collectors at the local, district, and exporter levels using a questionnaire, as well as data from search results related to literature.

\section{Work Procedure}

The stages of research implementation include: first, reviewing 2-3 attributes that have the highest RMS value in each dimension of sustainability (ecological, economic, social, technological and institutional dimensions) based on the results of previous research; second, creating a reference score based on the theory and results of previous research; third, collecting field data through structured interviews using questionnaires for cultivators, seaweed business players, and government staff related to important attributes in each dimension; and finally, providing a score for each attribute based on the data collected and a reference score. 


\section{Data Analysis}

The method used to reveal important factors in the sustainability of seaweed farming in Parigi Moutong Regency is the Multi-Dimensional Scaling (MDS) method using the RAPFISH (Rapid Appraisal for Fisheries) technic (Pitcher and Preikshot, 2001; Kavanagh and Pitcher, 2004; Pitcher et al., 2013). The MDS method is a multivariate analysis method that can handle non-metric data, and is a computer-based statistical analysis technique that transforms all dimensions of an activity's sustainability into reduced dimensions, but represents the constituent factors of all dimensions. The dimensions referred to in the study of the sustainability of seaweed farming include the ecological, economic, social, technological, ethical, and institutional (Lam, 2016) dimensions which are derived into several leveraging factors for sustainability.

The stages of the analysis are (Kavanagh and Pitcher, 2004): Determination and review of attributes that were completed during the preparation for the implementation of the modified survey and literature review.

Then, making the Attribute Score in the form of "bad score", "good score" and "intermediate score"; followed by Ordination of Rapfish using RAPFISH tools includes: (a) giving an assessment of the main horizontal reference point at the extreme point of "bad" given a score of $0 \%$ and the extreme point of "good" given a score of $100 \%$, (b) making another main reference point, namely the midpoint is bad and the midpoint is good, and the vertical direction reference point ("up" and "down") or also known as the "anchors" reference point is useful for the stabilizer, (c) standardize the score for each attribute so that each attribute have uniform weight and the difference between measurement scales can be eliminated, (d) calculating the distance between reference points using the euclidean distance squared (seuclied) method.

Afterward, calculating the Sustainability Status Index of seaweed cultivation which has a $0 \%-100 \%$ range, and is divided into four categories of sustainability status, namely $0-25.0 \%$ bad or not sustainable, $25.01-50.0 \%$ less or less sustainable, $50.1-75.0 \%$ enough or fairly sustainable, and 75.1 - 100.0\% good or very sustainable.

Finally, a sensitivity analysis is carried out to see which factors are the most sensitive to the sustainability index of seaweed cultivation. The sensitivity or importance level of each attribute can be seen from the value of "Root Mean Square" (RMS) on the X-axis. Testing the validity of the data and the accuracy of the analysis results using several tests, namely: (1) based on the value of "stress (standardized residual sum of a square)", the desired value of "stress" is less than 0.20 (stress $<20 \%$ ), (2) the coefficient of determination $\left(\mathrm{R}^{2}\right)$ should be $>50 \%$, and (3) the results of Monte Carlo ordination, good results if obtained narrow value interval (similar).

\section{RESULTS AND DISCUSSION Factors Review and Scoring}

Determination of the parameters of each factor according to the ecological, social, economic, technological, and institutional dimensions refers to general criteria obtained from several empirical studies. Meanwhile, the determination of reference and score categories are modified from several research results and refers to the general criteria for coastal resource management (Stelzenmüller et al., 2013; Martinez et al., 2017; de Alencar et al., 2020). Based on the results of research related to leveraging attributes (Marzuki et al., 2014; Effendy, 2016; Soejarwo et al., 2019; Irfan et al., 2020) in the institutional dimension, the suitable coastal area and utilization of coastal area are found as an important factor (indicated by a high RMS value). Price fluctuations and farming feasibility factors 
are important attributes in the economic dimension, while in the social dimension, the involvement of labor and socio-culture capital is obtained as factors that influence the sustainability of seaweed cultivation. The availability of superior seaweed seeds and the existence of small and mediumscale processing industries represent important factors in the sustainability of the technological dimension. Meanwhile, the leverage factor in the sustainability of the institutional dimension is represented by the institutional capacity of farmer groups and the institutional market guarantees. The scoring for ten attributes from five dimensions is adjusted to the real conditions of seaweed agribusiness management from the cultivator, marketer, and product processing level in the Parigi Moutong Regency. The determination of attributes (factors) and scoring of each attribute per dimension are presented in Table 1.

Table 1. The score of each factor per dimension of seaweed farming.

\begin{tabular}{|c|c|c|c|}
\hline Dimension & Factors or Attributes & Scoring & Scoring Reference \\
\hline \multirow[t]{2}{*}{ Ecological } & $\begin{array}{l}\text { Suitable coastal } \\
\text { area }\end{array}$ & 2 & $\begin{array}{l}0=<10 \% ; 1=10-25 \% ; 2=26-50 \% ; 3=>50 \% \\
\text { (Irfan et al., 2020) }\end{array}$ \\
\hline & Utilization rate & 1 & $\begin{array}{l}0=<10 \% ; 1=10-25 \% ; 2=26-50 \% ; 3=>50 \% \\
\text { (Yusuf et al., 2018) }\end{array}$ \\
\hline \multirow[t]{2}{*}{ Economic } & Price fluctuations & 0 & $\begin{array}{l}0=\text { decrease } ; 1=\text { fluctuate } ; 2=\text { relatively stable; } \\
3=\text { stable }\end{array}$ \\
\hline & Farming Feasibility & 1 & $\begin{array}{l}0=\mathrm{R} / \mathrm{C} \leq 1 ; 1=1<\mathrm{R} / \mathrm{C} \leq 2 ; 2=\mathrm{R} / \mathrm{C}>2 \text { (Azis, } \\
2011 \text { ) }\end{array}$ \\
\hline \multirow[t]{2}{*}{ Social } & Employment & 2 & $\begin{array}{l}0=\text { low }(<10 \%) ; 1=\text { medium }(10-20 \%) ; 2=\text { quite } \\
\text { high }(21-30 \%) ; 3=\text { high }(>30 \%) \text { (Pitcher and } \\
\text { Preikshot, 2001; Irfan et al., 2020) }\end{array}$ \\
\hline & $\begin{array}{l}\text { Socio-cultural } \\
\text { capital }\end{array}$ & 0 & $\begin{array}{l}0=\text { low; } 1=\text { less; } 2=\text { enough; } 3=\text { high (Irfan } e t \\
\text { al. } 2020 \text { ) }\end{array}$ \\
\hline \multirow[t]{2}{*}{$\begin{array}{l}\text { Techno- } \\
\text { logical }\end{array}$} & $\begin{array}{l}\text { Quality seeds of } \\
\text { seaweed }\end{array}$ & 0 & $\begin{array}{l}0=\text { unavailable; } 1=\operatorname{low}(<50 \%) ; 2=\text { medium } \\
(50-99 \%) ; 3=\text { available }(100 \%) \text { (Yong et al., } \\
2014 \mathrm{~b})\end{array}$ \\
\hline & Processing industry & 1 & $\begin{array}{l}0=\text { unavailable; } 1=\text { alkali treated Chips(atc); } 2= \\
\text { semi refined carrageenan (src); } 3=\text { refined } \\
\text { carrageenan (Eranza et al., 2017; Wartenberg et } \\
\text { al., 2017; van den Burg et al., 2021) }\end{array}$ \\
\hline \multirow[t]{2}{*}{ Institutional } & $\begin{array}{l}\text { Institutional } \\
\text { capacity of farmer } \\
\text { groups }\end{array}$ & 1 & $\begin{array}{l}0=\text { unavailable; } 1=\text { available } \& \text { ineffective; } 2= \\
\text { available \& enough effective; } 3=\text { available \& } \\
\text { effective (Lam, 2016) }\end{array}$ \\
\hline & $\begin{array}{l}\text { Institutional and } \\
\text { market guarantees }\end{array}$ & 2 & $\begin{array}{l}0=\text { unavailable; } 1=\text { available } \& \text { no guarantees; } \\
2=\text { available } \& \text { less guarantees; } 3=\text { available } \& \\
\text { certainly (Blankenhorn, 2007; Muthalib et al., } \\
\text { 2017) }\end{array}$ \\
\hline
\end{tabular}

Table 1 shows that the area of water suitable for seaweed cultivation is 61,615 hectares in Ampibabo, Kasimbar, and Mepanga Districts. The used water area is $7,429.49 \mathrm{Ha}$ or the level of utilization of coastal waters for seaweed cultivation has only reached $12.06 \%$. The economic dimension of the seaweed business shows that this activity is quite feasible to be carried out by people in coastal areas.
This is related to the relatively short production and the harvest period of 4045 days, low production costs, easy operation by household members, the price of commodities cultivated by the Parigi Moutong community in the early 2000s was quite high, and the source of seeds could be obtained by government assistance. Indonesia, resulting in a significant increase in production and 
income as well as the institutional capacity of cultivator groups.

However, in the last three years, fluctuations in production, declining commodity prices of seaweed, and the influence of the global market have delayed investment in the processing industry, and some farmers have left this business. In terms of the social dimension, seaweed farming activities can absorb more family and outside workers. This is because the types and stages of work are relatively simple and do not require special skills. The communication process between members of the cultivator group, communication between group members and the facilitator is still very low, and the nature of always hoping for further assistance causes low productivity and work motivation (Hussin et al., 2015).

The role of the head of the cultivator group is still very low in facilitating, motivating, and mobilizing its members in increasing the productivity and communication of the commodity marketing agency so that it is unable to become a price taker. Social capital is a communication relationship that is formed between community members, where there is the main actor (group leader) who plays a major role and becomes an important part of the community (Megyesi et al., 2011). The attribute quality seeds of seaweed in the technological dimension show that generally farmers only use local seeds that come from their harvest or buy from other farmers. Use of superior seeds only when given assistance by the government.
In the downstream sub-system, the existence of the seaweed processing industry and grass processing business into micro, small, and medium-scale food products is still limited. Also, the seaweed commodity trading chain in this region is relatively long. Product marketing actors involve cultivators, village-level collectors, sub-district-level collectors, district traders, wholesalers, and exporters. Purchase prices by collectors fluctuate in the range of IDR 7,500 - 13,500 per kg of dried seaweed.

\section{Sustainability of Seaweed Farming Sustainability Status}

The sustainability status of seaweed cultivation is a condition for the achievement of the results of seaweed cultivation by all business actors involved, starting from the environmental conditions of aquaculture, availability of production inputs, production processes, product processing, and marketing of seaweed commodities and the role of supporting institutions. The results of MDS analysis on the index and status of the sustainability of seaweed cultivation in Parigi Moutong Regency, Central Sulawesi Province are presented in Figure 1.

The results of testing the validity of the data and the accuracy of the results show a value of "stress" of 0.14 (stress $<20 \%$ ), the coefficient of determination $=$ $95.28 \%$ ( $>50 \%$ ), and the results of the Monte Carlo ordination showed a similar value for the 2 parameters, namely $37.85 \%$ for the scatter and $39.73 \%$ for the scatter plot.

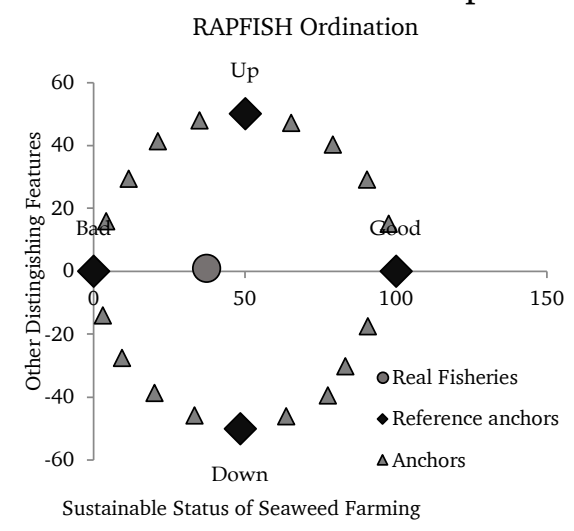

Figure 1. Sustainability Status of Seaweed Cultivation. 
Based on Figure 1, the index value for the sustainability of seaweed cultivation in Parigi Moutong Regency is 37.50 percent, which means that the business sustainability status is still in the less sustainable category. This index also means that the status of achievement of the results of the implementation of the development of seaweed cultivation in Parigi Moutong Regency has only reached 37.50 percent. The low index of the sustainability of the seaweed business shows that some dimensions and attributes have not been maximally achieved. If we look at the value of the attribute score for each dimension, the economic and technological dimensions have very low achievements, the achievement of the social and institutional dimensions is only in the medium category, causing the sustainability index to lead to the unsustainable category. The status of the sustainability of this seaweed cultivation is lower than the results of research by Irfan et al. (2020) which reached 50.42 percent. This shows that the expected goal of the current seaweed cultivation development program has not had a significant economic and institutional impact on the cultivator community in Parigi Moutong Regency.

\section{Leverage Factors of Seaweed Farming Sustainability}

The sustainability status of the development of seaweed cultivation in Parigi Moutong District, Central Sulawesi Province is determined by factors belonging to the dimensions of ecology, economy, social, technology, and supporting institutions. The value of leverage factors in influencing the sustainability index of cultivation is presented in Figure 2.

Leverage of Attributes

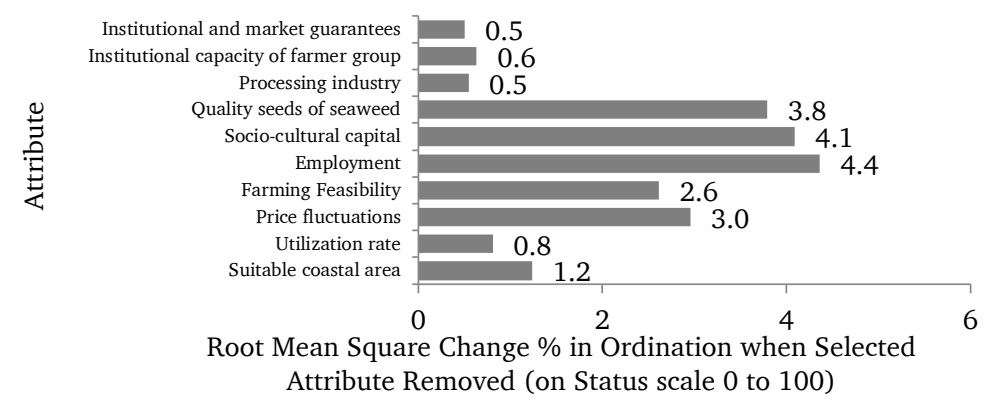

Figure 2. Leveraging Attributes for the Sustainability of Seaweed Cultivation.

Figure 2 shows that the factors of employment, socio-cultural, and the quality seed of seaweed are very dominant in influencing the sustainability status of seaweed cultivation. The results showed that the absorption of labor both from family and outside the family was very large in seaweed cultivation. This is in line with research by Irfan et al. (2020) which states that labor availability and cultural systems in seaweed cultivation are important factors in influencing the social sustainability status of seaweed management. The absorption of labor will also increase if it is followed by the growth of grass processing businesses on a micro and small scale with the types of products produced such as dodol, chips, seaweed sweets, and other ready-to-consume products.

Besides, efforts are needed to change the mindset and behavior of some seaweed cultivators who depend heavily on government and private assistance in the continuity of their cultivation businesses and reduce hopes for further assistance. On the technical side, the quality of the seeds used by cultivators is very low so that they are very vulnerable to ice-ice disease which has an impact on decreased production and sometimes causes the cessation of cultivation 
activities (Yong et al., 2014a). Another factor that is sufficient to have an impact on the low level of sustainability of seaweed cultivation is the fluctuation and decline in commodity prices for seaweed (Ferdouse et al., 2018). As a result of market uncertainty, long trade chains, a lack of processing industry, and ineffective seaweed commodity export policies, this has exacerbated the problem of commodity prices (Muthalib et al., 2017).

On the other hand, the results of the calculation of the economic feasibility of cultivation under normal conditions indicate the feasibility of being cultivated. This has implications for the role of the government which later can produce policy programs that lead to market provision for processed seaweed products (Irmayani et al., 2015), accelerate existence and partnerships with processing industries in the medium and large industrial scale (Laapo and Howara, 2016), and involve professional workforce, especially women (Swanepoel et al., 2020). Besides, policies are needed to facilitate efforts related to increasing knowledge and skills (processing technology) for the community, and collaboration with research and development institutions for appropriate technology (Blankenhorn, 2007; Ginigaddara et al., 2018). At the same time, the government must also accelerate the preparation of basic infrastructures such as electricity, transportation infrastructure, and facilities to support increased production (Hasselström et al., 2018; van den Burg et al., 2021).

\section{CONCLUSION}

The conclusion that can be drawn from this paper is that the sustainability status of the seaweed cultivation in Parigi Moutong Regency is in the less sustainable category. Important factors that make the main lever of the sustainability status of seaweed farming are high employment, socio-cultural capital, and the low-quality seed of seaweed. To maintain and increase the absorption of labor in rural areas, and the sustainable farming feasibility of seaweed cultivation, improvements are needed in the socio-cultural capital factors of members of cultivator groups, improvement, and continuity of supply of quality seeds, and reduce price fluctuations for seaweed commodity through chain improvements, trading, manufacturing investment, and partnerships with companies.

\section{ACKNOWLEDGMENT}

The authors are grateful to the government through the Department of Marine Affairs and Fisheries of Central Sulawesi Province for providing research funding assistance, and also to the respondents, and seaweed traders from village level to the exporters who have provided data and information of this paper.

\section{REFERENCES}

de Alencar, N.M.P., Le Tissier, M., Paterson, S.K. and Newton, A., 2020. Circles of coastal sustainability: a framework for coastal management. Sustainability, 12(12), p.4886. https://doi.org/10. 3390/su12124886

Arsyad, M., Nuddin, A., Zamhuri, M.Y. and Yusuf, S., 2014. The Poverty Reality of Coastal and Agriculture: How Severe the Seaweed Farmers and Cocoa Smallholders Are?. International Journal of Agriculture System, 2(2), pp.119-131. http://dx .doi.org/10.20956/ijas.v2i2.28

Azis, H.Y., 2011. Optimasi Pengelolaan Sumberdaya Rumput Laut Di Wilayah Pesisir Kabupaten Bantaeng Provinsi Sulawesi Selatan. http://rep ository.ipb.ac.id/handle/12345678 9/46681.

Blankenhorn, S.U., 2007. 'Seaweed farming and artisanal fisheries in an Indonesian seagrass bed Complementary or competitive usages ?', Exchange Organizational Behavior Teaching Journal, 2, p.118.

BPS, 2020. Provinsi Sulawesi Tengah dalam Angka 2020. Edited by Bidang 
Integrasi Pengolahan dan Diseminasi Statistik. Kota Palu: BPSStatistics of Sulawesi Tengah Province.

van den Burg, S.W.K., Dagevos, H. and Helmes, R.J.K., 2021. Towards sustainable European seaweed value chains: a triple $\mathrm{P}$ perspective. ICES Journal of Marine Science, 78(1), pp.443-450. https://doi.org/10.109 3/icesjms/fsz183

Chen, H., 2019. Bayesian inference of environmental effects on seaweed production in Japan via a production-environmental suitability model. Botanical studies, 60(1), pp.1-10. https://doi.org/10.1186/s 40529-018-0250-x

Effendy, S., Hasanuddin, A., Tantu, F.Y. and Laapo, A., 2016. Determining Potential Volume of Raw Dried Seaweed Kappaphycus Alvarezii Based on Land Suitability as Agribusiness Management Plan. Journal of Economics and Sustainable Development, 7(20), pp.58-66. https://www.iiste.org/Journals/ind ex.php/JEDS/article/view/33696

Effendy, S., 2016. Optimization Management Model on Sustainable Agribusiness Development of Seaweed Kappaphycus alvarezii in the PArigi Moutong District, Central Sulawesi Province. Tadulako.

Ellis, J.I., Clark, M.R., Rouse, H.L. and Lamarche, G., 2017. Environmental management frameworks for offshore mining: the New Zealand approach. Marine Policy, 84, pp.178192. https://doi.org/10.1016/j.mar pol.2017.07.004

Eranza, D.R.D., Bahron, A., Alin, J., Mahmud, R. and Malusirang, S.R., 2017. On-Going Assessment of Issues in the Seaweed Farming Industry in Sabah, Malaysia. Journal of the Asian Academy of Applied Business (JAAAB), 4, pp.49-60. https://doi.org/10.51200/jaaab.v0i 0.1290

Erlania, E. and Radiarta, I.N., 2014. Management of sustainable seaweed
(Kappaphycus alvarezii) aquaculture in the context of climate change mitigation. Indonesian Aquaculture Journal, 9(1), pp.65-72. http://dx.d oi.org/10.15578/iaj.9.1.2014.65-72

Ferdouse, F., Holdt, S.L., Smith, R., Murúa, P. and Yang, Z., 2018. The global status of seaweed production, trade and utilization. Globefish Research Programme, 124, p.

Ginigaddara, G.A.S., Lankapura, A.I.Y., Rupasena, L.P. and Bandara, A.M.K.R., 2018. Seaweed farming as a sustainable livelihood option for northern coastal communities in Sri Lanka. Future of Food: Journal on Food, Agriculture and Society, 6(1), pp.57-70. http://www.thefutureoff oodjournal.com/index.php/FOFJ/a rticle/view/11

Hasselström, L., Visch, W., Gröndahl, F., Nylund, G.M. and Pavia, H., 2018. The impact of seaweed cultivation on ecosystem services - a case study from the west coast of Sweden. Marine Pollution Bulletin, 133, pp.53-64. https://doi.org/10.1016/ j.marpolbul.2018.05.005

Husrin, S., Prihantono, J. and Softyan, H., 2016. Impacts of Marine Sand Mining Activities to the Community of Lontar Village, Serang-Banten. Bulletin of the Marine geology, 29(2), pp.81-90. http://dx.doi.org/10.326 93/bomg.29.2.2014.68

Hussin, R., Yasir, S.M., Kunjuraman, V. and Hossin, A., 2015. Enhancing capacity building in seaweed cultivation system among the poor fishermen: A case study in Sabah, East Malaysia. Asian Social Science, 11(18), pp.1-9. https://doi.org/10. 5539/ass.v11n18p1

Irfan, M., Abdullah, N., Yuliana, Samadan, G.M. and Subur, R., 2020. Sustainability Status of Seaweed Kappaphycus alvarezii Cultivation in Posi-Posi Waters, South Kayoa Subdistrict, Regency of South Halmahera, Province of North Mollucas, Indonesia. International Journal of Advanced Science and 
Technology, 29(8), pp. 806-817. http://sersc.org/journals/index.php /IJAST/article/view/19226

Irmayani, Yusuf, S. and Arsyad, M., 2015. Increasing Farmer's Income with Production of Seaweed Eucheuma cottonii sp. Advances in Economics and Business, 3(3), pp.83-92. DOI: 10.13189/aeb.2015.030301.

Jalil, A.R., Samawi, M.F., Azis, H.Y., Jaya, I., Malik, A., Yunus, I. and Sohopi, M.A.A., 2020. Comparison of physical-chemical conditions for seaweed cultivation in the Spermonde Archipelago, Indonesia. Aquaculture, Aquarium, Conservation \& Legislation, 13(4), pp.2071-2082. http://www.bioflux. com.ro/docs/2020.2071-2082.pdf

Kavanagh, P. and Pitcher, T.J., 2004. Implementing Microsoft Excel software for Rapfish: a technique for the rapid appraisal of fisheries status. Fisheries Centre Research Reports, 12(2), p.75. https://dx.doi. org/10.14288/1.0074801

Laapo, A. and Howara, D., 2016. Coastal community welfare improvement through optimization of integrated pond farming management in Indonesia. International Journal of Agriculture System, 4(1), pp.73-84. http://dx.doi.org/10.20956/ijas.v4i 1.247

Lam, M.E., 2016. The ethics and sustainability of capture fisheries and aquaculture. Journal of Agricultural and Environmental Ethics, 29(1), pp.35-65. DOI: 10.1007/s10806-015-9587-2.

Martinez, M.L., Taramelli, A. and Silva, R., 2017. Resistance and resilience: facing the multidimensional challenges in coastal areas. Journal of Coastal Research, 77(10077), pp.1-6. https://doi.org/10.2112/SI 77-001.1

Marzuki, M., Nurjaya, I.W., Purbayanto, A., Budiharso, S. and SUpriyono, E., 2014. Sustainabiliy Analysis of Mariculture Management In Saleh Bay of Sumbawa District.
Environmental Management and Sustainable Development, 3(2), pp. 127-137. https://doi.org/10.5296/ emsd.v3i2.6427

Megyesi, B., Kelemen, E. and Schermer, M., 2011. Social capital as a success factor for collective farmers marketing initiatives. The International Journal of Sociology of Agriculture and Food, 18(1), pp.89103. https://doi.org/10.48416/ijsaf .$v 18 \mathrm{i} 1.260$

Muthalib, A.A., Putra, A., Nuryadi, A.M. and Afiat, M.N., 2017. Seaweed business conditions and marketing channels in coastal district of Southeast Sulawesi. The International Journal of Engineering and Science, 6(10), pp.35-41. DOI: 10.9790/1813-0610013541.

Pitcher, T.J., Lam, M.E., Ainsworth, C., Martindale, A., Nakamura, K., Perry, R.I. and Ward, T., 2013. Improvements to Rapfish: A rapid evaluation technique for fisheries integrating ecological and human dimensions. https://doi.org/10.111 $1 / \mathrm{jfb} .12122$

Pitcher, T.J. and Preikshot, D., 2001. RAPFISH: a rapid appraisal technique to evaluate the sustainability status of fisheries. Fisheries Research, 49(3), pp.255270. https://doi.org/10.1016/S016 5-7836(00)00205-8

Rech, S., Borrell Pichs, Y.J. and GarcíaVazquez, E., 2018. Anthropogenic marine litter composition in coastal areas may be a predictor of potentially invasive rafting fauna. PloS one, 13(1), pp.1-22. https://do i.org/10.1371/journal.pone.019185 9

Soejarwo, P. A., Yusuf, R. and Zulham, A., 2019. Analisis Keberlanjutan Usaha Budi Daya Rumput Laut Di Sumba Timur, Nusa Tenggara Timur. Jurnal Sosial Ekonomi Kelautan dan Perikanan, 14(1), pp.37-46. http:// dx.doi.org/10.15578/jsekp.v14i1.7 815 
Stelzenmüller, V., Schulze, T., Gimpel, A., Bartelings, H., Bello, E., Bergh, Ø., Bolman, B., Caetano, M., Davaasuren, N., Fabi, G., Ferreira, J. G., Gault, J., Gramolini, R., Grati, F., Hamon, K., Jak, R., Kopke, K., Laurans, M., Mäkinen, T., ... VernerJeffreys, D., 2013. Guidance on a Better Integration of Aquaculture. Fisheries, and other Activities in the Coastal Zone: Froom tools to practical examples. COEXIST project. ISBN: 978-0-9926602-0-8.

Swanepoel, L., Tioti, T., Eria, T., Tamuera, K., Tiitii, U., Larson, S. and Paul, N., 2020. Supporting women's participation in developing a seaweed supply chain in Kiribati for health and nutrition. Foods, 9(4), p.382. https://doi.org/10.3390/foo ds9040382

Topcon, C., 2014. Evaluation of the Implementation of Aquaculture PUMP in Zone II of Central Sulawesi Province. Palu.

Valderrama, D., Cai, J., Hishamunda, N. and Ridler, N., 2013. Social and economic dimensions of carrageenan seaweed farming. FAO Fisheries and Aquaculture Technical Paper.

Wartenberg, R., Feng, L., Wu, J.J., Mak, Y.L., Chan, L.L., Telfer, T.C. and Lam, P.K., 2017. The impacts of suspended mariculture on coastal zones in China and the scope for integrated multi-trophic aquaculture. Ecosystem Health and Sustainability, 3(6), p.1340268. https://doi.org/10.1080/20964129 .2017 .1340268

Yong, W.T.L., Chin, J.Y.Y., Thien, V.Y. and Yasir, S., 2014. Evaluation of growth rate and semi-refined carrageenan properties of tissue-cultured Kappaphycus alvarezii (Rhodophyta, Gigartinales). Phycological Research, 62(4), pp.316-321. http://dx.doi.or g/10.1111\%2Fpre. 12067

Yong, W.T.L., Ting, S.H., Yong, Y.S., Thien, V.Y., Wong, S.H., Chin, W.L., Rodrigues, K.F. and Anton, A., 2014.
Optimization of culture conditions for the direct regeneration of Kappaphycus alvarezii (Rhodophyta, Solieriaceae). Journal of Applied Phycology, 26(3), pp.1597-1606. https://doi.org/10.1007/s10811-01 3-0191-4

Yusuf, M., Cocon, Anggoro, S., Sugianto, D.N. and Alifdini, I., 2018. Sustainability status of the ecological dimension in the management of mariculture development area (Case study in Ekas Bay, East Lombok Regency, West Nusa Tenggara Province, Indonesia). Asian Journal of Microbiology, Biotechnology and Environmental Sciences, 20(3), pp.329-338. http://www.envirobio techjournals.com/article_abstract.p hp?aid $=9005 \&$ iid $=260 \&$ jid $=1$ 